\title{
The Professional Careers: Women Pioneers and the Male Image Seduction
}

\author{
Rachel Finnegan
}

\author{
Royal Irish Academy \\ Dublin
}

An idea of just how the female was perceived by a thinking Athenian male can be judged from a statement made by the philosopher and polymath, Aristotle. In his Politics, he discusses the idea of rulers and subjects. Having stated that it is advantageous for animals (whether wild or tame) to be governed by men, he then asserts: 'Also, as between the sexes, the male is by nature superior and the female inferior, the male ruler and the female subject.'(1) Such a concept explains and justifies why it has been necessary, throughout history, for men to hold power over women.

Earlier examples of this justification take the form of charter or matriarchal myths.(2) In accordance with this Aristotelian dictum, the sources, with revelations about double-standards in relation to women's position in society and in law, and the obvious anti-female tendencies - particularly towards those of the less respectable classes - present a very dismal picture to the modern reader of the West. The custom of seclusion made it impossible for women of the 'respectable' classes to pursue a profession - at least outside the home - and a question which has been hotly debated for many years is whether or not this system reflects men's distrust or hatred of the sex.(3)

As vividly illustrated in Xenophon's Oeconomicus - a famous treatise on household matters - the duty of a woman or wife (the same word, gyne, sufficed for both) was to manage the internal affairs of the household, while that of the man was to deal with matters outside the home.(4) Together with producing heirs to the estate, and taking part in various obligatory religious rituals, household management was a woman's sole occupation in life, and as such, the amount of education she required was minimal. It is not until the end of the fourth and the third-centuries BC. that we start to find evidence of education and schooling for girls in the Greek world.(5)

The whole subject of respectable women was taboo in Classical Athens, to the extent that it was frowned upon to even mention them by name in public - a convention realistically presented even in the otherwise unconventional world of comedy.(6) Given this, together with the fact that their life-style was hardly conducive to inspiration or creativity in the arts, it is not surprising that one of the major proofs of female literacy - literary production - is almost non-existent. Other sources, such as vase-paintings with scenes of women reading or writing, are often misleading and difficult to interpret, since subjects which have always been thought to represent ordinary women, often turn out to be Muses or the poetess Sappho.(7)

Whatever the degree of literacy among Athenian women, it is clear that only those from the less respectable classes of society, the old, or those whose families had fallen on hard times, worked outside the home. Even then, however, the occupations they undertook could hardly be described as professional careers, but rather, as the least condemnable means of earning a wage (as opposed, for instance, to prostitution). Such work included street or market-vending (which may have involved the actual production of wares), midwifery, matchmaking and child-care. The women themselves were regarded as inferior since they were not only engaged in lowly trades outside the home, but worked side-by-side with metics (resident aliens) and slaves, and necessarily came into contact with men - the avoidance of which was clearly the primary aim of keeping women at home in the first place.

Such a prejudicial attitude is apparent in a legal oration involving a man by the name of Euxitheus who had lost his rights of citizenship because his mother was a nurse and a ribbon-seller and, therefore, was assumed to be a non-citizen. (8) Demosthenes succeeded in helping his client regain his citizen status by defending the mother and other citizen women like her, who had clearly been reduced to such a life-style through pressure of continued war. When husbands went away to war for years on end, or died on the battle-field, women were often faced with the prospect of taking up some lowly job to keep the family from starvation.

However repressive a society, it is inevitable that there are always some exceptions to the general rule, and throughout history there are examples of various women who actually did manage - against all opposition - to pursue their chosen career and achieve fame - even if it meant dressing up and posing as a man! Closer to our own time, we can think of slightly less extreme situations in which English novelists had to adopt men's names in order to have their works accepted by publishers: women such as George Eliot (who is still known by this pseudonym) and the three Bronte sisters - Acton (Alice), Currer (Charlotte) and Ellis (Emily). It is significant that most of the 'influential' women from the period we are dealing with were particularly concerned with what we nowadays call women's 'issues'. This is, perhaps, because they were writing on, or in other ways concerned with, those matters which most affected them, in the same way that men - as is evident from the sources - were prone to concentrate on peculiarly male affairs. What is more interesting, however, is the contemporary male attitude to such women and their achievements, which is generally one of ridicule or 
condemnation.

With regard to writing - what we would possibly regard as the most respectable and genteel of occupations - the seventhcentury poetess, Sappho, dedicated many of her love-songs to other women and girls.(9) Similarly, Erinna, another poetess writing in the mid-fourth-century BC, is famous for a poem she composed in memory of her dear friend Baucis a young girl who was always at her side (GLP 3.120). Both these women dwelt on themes of the close friendships of young girls - Sappho in particular presenting the idea of happiness and innocence in childhood, and the horror of being snatched away from friends at an early age and forced into unwelcome marriage.(10)

Although the work of Sappho has been greatly admired and imitated by poets through the ages, it was continually mocked by the Athenian comic playwrights, who gave the word "lesbian" (the adjective deriving from her birth-place) obscene connotations.(11) The work and private life of Erinna, and her close friend Baucis, are similarly derided by the Alexandrian mimographer, Herodas, who, in his Mimes, uses them as comic names for olisboi (dildos);(12) and if this sort of smutty male reaction to female writers is not bad enough, commentators on their works - both ancient and modern - have further diminished the reputation of such literary talent and skill by actually denying female authorship. (13) Another example is the poetess Corinna, (of Thebes or Tanagra), who defeated Pindar five times in poetry contests and was rewarded for giving him some literary advice by being referred to in a later poem as a 'Boeotian sow'(14) - the sow being a common term of abuse used of women in the Greek world.(15) Likewise, the fifth-century poetess Praxilla wrote a Hymn to Adonis, which was duly ridiculed by other members of the literary circle.(16)

From writing, we turn to philosophy - an activity less likely to include women, since its practice often involved the discussion of theories in groups or sects. There are exceptions, however: the life and works of the sixth-century Pythagoras - known even then as the 'Feminist Philosopher' - are said to have been greatly influenced by various women. He learned most of his moral doctrines from the Delphic Priestess, Themistoclea, and - having established a Pythagorean community in the Greek colony of Croton, in southern Italy (an order which included at least twenty-eight female teachers and students), he married a famous cosmologist, Theano, who wrote treatises on mathematics, physics and medicine. Both she and her daughters were particularly interested in gynaecology and when the school was destroyed and Pythagoras killed, Theano succeeded him as leader of the community. We are told by Diogenes Laertius, who is the most important source for female philosophers,(17) that men gave their wives into the charge of Pythagoras to learn his doctrines.

Inevitably, the comic poets satirised this aspect of the Pythagorian community. We have fragments of two comedies entitled Pythagorizousae or Pythagorising Women - one the work of Cratinus and the other by Alexis.(18) Although only a few lines of each exist, it can be imagined that - as indicated by the titles - this unusual situation of influential and intellectual females was satirised to its fullest extent. Other famous women associated with later branches of the Pythagorean School included Phintys and Milissa who, in the fifth-century BC, wrote on the obligations of women.

Diogenes Laertius also records that around 300 BC a young Mantinean woman by the name of Hipparchia became fascinated by the doctrines of the Cynic philosophy and, more especially, by the Theban philosopher, Crates.(19) She was so obsessed that she not only refused to marry several eligible suitors but threatened suicide if her parents did not arrange her marriage with the man. The philosopher himself tried to dissuade her, to no avail, and eventually informed her that if she wished to marry him she would have to adopt his career - which would necessarily involve posing as a man. Having agreed to this, she then had to masquerade as a man in order to pursue her interest in philosophy - and was thus able to live the life of a Cynic.

She is reputed to have accompanied her husband to dinners and other public events and evidently incurred the wrath of the male guests. According to one tale, she annoyed a certain Theodorus by one of her quips, or sophisms, causing him to rip off her cloak and ask why she has given up weaving. Her reply was to the effect that the pursuit of education is more important than the loom. Other female philosophers include the Platonists Lastheneia of Mantinea and Axiothea of Phlius - the latter of whom was also reputed to have worn men's clothing.(20) She was, therefore, accepted in intellectual circles by a means which was to be adopted by many later female scholars.

The logic behind such an extreme requirement is difficult to follow: if a woman was actually accepted into a sect on the basis of the necessary credentials (presumably, the virtue of her superior mind), why was it obligatory for her to become, or seem to become, a man just because philosophy was traditionally a male preserve? In the case of Hipparchia, her admittance to the Cynic way of life was, perhaps, based partly on her wealth (which would have involved a large dowry for Crates) and the fact that her brother Metrocles also belonged to the sect.(21) Perhaps - like the Spartan marriage ritual of a bride cropping her hair and wearing men's clothes(22) the measure of trans-dressing was taken to put other members at ease in this unaccustomed female presence. Another interpretation could be that the sect did not wish to be regarded as having courtesans in its midst, and so insisted on its female components looking as little as possible like courtesans, who were easily identified by their colourful clothes, elaborate hair-styles and heavy make-up.(23) Whatever the case, that such a custom was not considered particularly unusual is indicated, perhaps, by the reaction of the historian, who simply records the facts without further comment.

We come now to the question of women's participation in the medical profession. We know from various iconographic and literary sources that women in childbirth were either assisted by female friends and neighbours, or employed a midwife.(24) One suspects that such work required, or rather, was given, little training, and depended mainly upon experience. It seems, too, that it was the particular preserve of old woman, who, in the Classical period, enjoyed a 
greater degree of freedom than the younger women.

It was perhaps perceived that once they had passed the age of child-bearing they were no longer affected by superstitious beliefs concerning sterility, which is why they alone, of all women, could take an active role in the slaughtering of sacrificial victims.(25) Neither were they concerned with marriage prospects or the threat of producing illegitimate children. Judging from the explanation in Demosthenes, mentioned earlier, and the reasons women had for going into this sort of work (for example poverty and war), such a job would also have been regarded with scant esteem. Given the fear, especially in the Classical period, of women coming into contact with men outside their own immediate family, it would have been ideal for such work to have been undertaken, properly, by women; but, as the following story reveals, such opportunities did not exist and because of this, patients had to be involved in considerable expense for the privilege of a trained, male physician or otherwise had to resort to some sort of unprofessional female help. Not surprisingly, the rates of infant mortality and mothers dying in childbirth were extremely high.(26)

As a glance at the extensive Hippocratic Corpus will show, the medical profession proper was a completely closed shop - and even the area of gynaecology was (as it is now) dominated by men. A strange story is recorded by the Roman historian Hyginus, (27) telling of an incident which is supposed to have occurred in fourth-century Athens, at around the same period as the tale about Hipparchia the Cynic. According to his report, the citizen women of Athens (presumably those of the wealthier classes) - too modest to see male doctors - were fast dying out in childbirth, and as the result of other female complaints. A young Athenian maiden called Agnodike (or Hagnodike, which translates as 'Chaste in Justice'), wishing to resolve the problem, cut off her hair, dressed up as a man and went to Alexandria, in $300 \mathrm{BC}$, where she studied medicine and midwifery under Herophilus, a famous doctor. On her return to Athens, still disguised as a man, she set up a practice and in order to put her reluctant patients at their ease, would lift up her cloak and reveal her true sex. She became so popular among female patients, however, that the male doctors - jealous of her success and eager to protect their profession - had her prosecuted on a charge of corrupting men's wives - a charge which relates to the Hippocratic Oath sworn by doctors even today.

In court, she surprised the whole company by lifting up her cloak and revealing herself to all as a woman. In this way, she inflicted two different charges on herself: first, that of being a woman physician, and secondly practising under false pretences. On hearing that their heroine was about to be sentenced to death, the furious women of Athens assembled at the law-courts, condemning their husbands as enemies rather than friends, and threatening that they would all die with her if she were put to death. Their protest succeeded and Agnodike was allowed to practice medicine as a woman. The law was changed and it became possible for free-born Athenian women to work in the medical profession so long as they treated females only.

This little-known tale could be interpreted in a variety of ways: firstly, as conforming to a certain type of myth involving the element of the symbolic exposure of the genitals (anasyrmos)(28) - something like the phenomenon of our Sheelana-gigs; secondly, as corresponding with comic scenes of travesty, with male actors playing female roles, and the added complication of then posing as men;(29) and thirdly, as a historical account of the development of the movement towards women's education in the medical field. There is little proof, though, either way - except for the fact (which may or may not be significant) that a funerary stele dating from the fourth-century BC describes a certain Phanostrate as a midwife and physician.(30) This indicates (irrespective of Hyginus' tale) that the practice of obstetrics was beginning to be undertaken by women from the fourth-century onwards.

If true, the element of female travesty in this story differs from the others outlined above. Rather than being made a stipulation by the men in charge, this method of dress is adopted secretly, as a means of entering illegally into a maledominated profession. Whereas the various philosophical schools in question acknowledged and accepted the intellectual capabilities of certain women, members of the medical profession chose to deny or ignore them.

One interpretation to be deduced from this is that the choice of acceptance on the one hand, and rejection on the other, depended on financial considerations. Although the comic poets would have us believe otherwise,(31) philosophy was not a profit-making organisation or profession, whereas medicine was. Therefore, a woman like Hipparchia might be allowed to practice philosophy among the Cynics, and possibly, at the same time, contribute financially by means of a dowry. This, however, was not a prerequisite for her entry, as indicated by the admission of other, less wealthy women.

As the story of Agnodike suggests, women in general were barred from the medical profession because the closed brotherhood of physicians wished to remain exclusive to members of their own sex. The latter cannot have believed that women were incapable of such work, since not only did they have an existing role in medicine (i.e. their employment as midwives), but their gradually increasing participation in education, and the resulting attributes in academic pursuits such as philosophy, cannot have gone unnoticed by educated members of the opposite sex. Rather, the doctors sought to keep women out of the medical world in a further attempt to keep the profession, and therefore the profits, to themselves.

According to the tale, at least, Agnodike, was accepted (conditionally) in intellectual circles and into a profession. Her acceptance, however, was based on the fact that she, like Hipparchia and their successors through the ages, was prepared to forgo her femininity to take up a chosen career in the male-dominated Greek world. 


\section{FOOTNOTES}

1. I.ii, 12-13.

2. On the subject of ancient matriarchal myths, see J. Bamberger, 'The Myth of Matriarchy: Why Men Rule in Primitive Society', in M. Z. Rosaldo \& L. Lamphere (eds), Women, Culture and Society. A Theoretical Overview (Stanford 1974), 263ff. and S. Pembroke, 'Women in Charge: the Function and the Ancient Idea of Matriarchy', JWI 30 (1967), $1 \mathrm{ff}$.

3. The question of 'contempt' has been denied by some scholars, e.g. C. Seltman, Women in Antiquity (London 1956) 111 and D. C. Richter, 'The Position of Women in Classical Athens, CJ (1971), $1 \mathrm{ff.}$

4. VII, 22-28.

5. For an interesting study on the subject, see S. Pomeroy, 'Technikai kai Musikai: the Education of women in the Fourth Century and in the Hellenistic Period', AJAH 2 (1977) 51ff.

6. This is an intriguing phenomenon, which has been examined and tested out in various types of literature. See, for instance, D. Schaps, 'The Women Least Mentioned: Etiquette and Women's Names', CQ N.S. 27 (1977) $223 \mathrm{ff}$. and A. Sommerstein, 'The Naming of Women in Greek and Roman Comedy', QS 6 (1980) 393ff.

7. On the difficulties of assessing literacy among Greek women, see S. Guettel Cole, 'Could Greek Women Read and Write?', in H. P. Foley (ed.) Reflections of Women in Antiquity (New York 1981) 219ff.

8. Demosthenes LVII, 35-36.

9. E.g. fr. 31, Poetarum Lesbiorium Fragmenta (eds), E. Loebel \& D.L. Page (Oxford 1955).

10. Tragic heroines and female choruses occasionally express similar views - cf. the chorus in Euripides' Phoenician Women 1672ff. and the Danaids, Aeschylus, Suppliant Women, who resist marriage proposals. Procne, however, has been less successful and has had to accept the foreign husband assigned to her by her father (Sophocles, fr. 521).

11. E.g. Aristophanes, Wasps 1346 and Ecclesiazusae 920.

12. 6. 20 and 7. 57-58. See R. Finnegan, 'Women in Herodian Mime', Hermathena CLII (1992) 21ff., esp. n.18.

13. See, for example, D. Page, Sappho and Alcaeus (Oxford 1955) 145, n.1, who rejects the view that Sappho, fr. 99, 1.5 is actually the work of Alcaeus.

14. See J. M. Edmonds, Lyra Graeca, iii, 644 and refs.

15. E.g. Phocylides fr. 2, 3 and Semonides The Female Mind, 2, both of whom claim that the tribes of women originated from a 'bristled sow'. See H. Lloyd-Jones, Females of the Species: Semonides on Women (London 1975), 64-65, n.2.

16. For a more favourable, modern, view, see T. F. Higham \& C.M.Bowra, The Oxford Book of Greek Verse in

Translation (Oxford 1938, repr. 1950), 725, n.409.

17. Vit. Pyth. xxi.

18. Kock II, 290 and 370, respectively.

19. VI, 96-98.

20. Diog. Laert. III, 46.

21. Ibid, VI, 96.

22. Plutarch, Lycurgus, XV,3. See P. Cartledge, 'Spartan Wives: Liberation or Licence?', CQ 75 (1975) 84ff., esp. 101. 23. Cf. the marvellous description in Athenaeus XIII, 568, a-d (from Alexis' comic play Fair Measure ) of the various ways of beautifying ugly prostitutes. The wearing of excessive cosmetics was considered a mark of vulgarity, not to be encouraged in respectable wives - cf. Xenophon, Oeconomicus, X, 2ff. where Ischomachus censures 'false glosses', and believes that women should exhibit only natural beauty.

24. Such female roles are comically reflected in the comedies of Aristophanes: e.g., Ecclesiazusae 528ff., where Praxagora uses her presence at a friend's birth as a fictitious excuse for her absence from the home; and the description of a feigned pregnancy in Thesmophoriazusae 502ff., where an aged nurse and the fake mother produce an infant from a jar and inform the elderly husband that it is his own. More realistic examples are mentioned in inscriptions - e.g. the "Nurses" in IG II, iii 4195-97. See H. McClees, A Study of Women in Attic Inscriptions (New York 1920).

25. See M. Detienne, 'Violentes "Eugenies" en Pleines Thesmophories: des Femmes Couvertes de Sang', in M. Detienne \& K.-P. Vernant (eds), La Cuisine de Sacrifice en Pays Grec (Paris 1979) 203ff.

26. IG III, ii, 1320 and 1384, for example, are grave inscriptions for women giving the cause of death as childbirth. Further testimony are the many grateful dedications by women to Eilythuia for bringing about successful births (e.g. IG II, ii, 1590).

27. Fabula 274, 10-13.

28. See H. King, 'Agnodike and the Profession of Medicine', PCPhS 212 N.S. 32 (1986) 53ff, but esp. 64ff.

29. The most obvious example in Attic comedy is the plot of Aristophanes' Ecclesiazusae, where the women of Athens, disguised in their husbands' clothes, sneak into the Assembly and vote for women's rule. For the dramatic implications of this comic device, see L. K. Taaffe, Women \& Aristophanes (London and New York 1993), esp. $103 \mathrm{ff}$.

30. IG II, iii 2343.

31. Cf. the caricature of Socrates in Aristophanes' Clouds 